\title{
FACTORS LIMITING SEED GERMINATION OF TERRESTRIAL BROMELIADS IN THE SANDY COASTAL Plains (RESTinga) OF MARICÁ, RIO de JANEIro, BRaZIL ${ }^{1}$
}

\author{
André Mantovani ${ }^{2}$ \& Ricardo Rios Iglesias ${ }^{3}$
}

\begin{abstract}
(Factors limiting seed germination of terrestrial bromeliads in the sandy coastal plains (restinga) of Maricá, Rio de Janeiro, Brazil) Vegetation islands surrounded by bare sand are one of the most characteristic features of the sandy plains (restinga) of the Brazilian coastline. Abiotic conditions outside the islands are too harsh for the establishment of plants. Bromeliads are frequent both inside and at the borders of islands, but infrequent outside the islands in the restinga of Maricá. We hypothesized that the rarity of bromeliad seedlings in the restinga is due to high mortality during the seed and/or seedling stages. In this study, we assessed the potential limiting factors for germination and seedling survival of three terrestrial bromeliads Neoregelia cruenta, Aechmea nudicaulis and Vriesea neoglutinosa. Seed viability, water balance during dry-wet cycles, germination under different water potentials and the susceptibility of seedlings to high temperatures, desiccation and sand burial were analyzed. The tested seeds were nondormant, and they germinated to $>70 \%$ even after exposure to $60^{\circ} \mathrm{C}$ and desiccation. At temperatures $>27^{\circ} \mathrm{C}$, seeds lost water faster than imbibited it, and drywet cycles and water potentials of $-0.4 \mathrm{MPa}$ decreased germination. Thus, low water availability is likely limiting factor for bromeliad seed germination in the restinga of Maricá. Seedlings were extremely sensitive to high temperatures and sand burial. Shoots failed to emerge if seed depth exceeded $10 \mathrm{~mm}$. We suggest that unequal temporal distribution of rainfall, low water retention capacity of the soil, and high temperatures inhibit germination and seedling establishment through water stress. Consequently, bromeliads are not likely to act as pioneer plants in the barren regions that separate restinga islands.
\end{abstract}

Key words: seedling survival, growth, temperature, sandy coastal plains.

\section{Resumo}

(Fatores limitantes para a germinação de sementes de bromélias terrestres da restinga de Maricá, Rio de Janeiro, Brasil) Moitas de vegetação separadas por areia ocorrem freqüentemente nas planícies costeiras brasileiras. Condições abióticas nas áreas entre moitas são estressantes para o estabelecimento vegetal. $\mathrm{Na}$ restinga de Maricá, bromélias são freqüentes dentro e na borda das moitas, sendo mais raras nas áreas entre moitas. Lança-se a hipótese de que a raridade de plântulas de bromélias nas áreas entre moitas seja devida à alta mortalidade durante a fase de semente ou plântula. Neste estudo, foram acessados potenciais fatores limitantes para a germinação e sobrevivência de três espécies de bromélias terrestres: Neoregelia cruenta, Aechmea nudicaulis e Vriesia neoglutinosa. Foram analisadas a viabilidade das sementes, o balanço hídrico sob ciclos de seca e hidratação, a germinação sob diferentes potenciais hídricos e a susceptibilidade das plântulas a altas temperaturas, dessecação e soterramento. As sementes não se mostraram dormentes e apresentaram germinabilidade acima de $70 \%$, mesmo após exposição a $60^{\circ} \mathrm{C}$ e à dessecação. Sob maiores temperaturas $\left(>27^{\circ} \mathrm{C}\right)$, as sementes perderam água mais rapidamente do que embeberam. Ciclos de seca e hidratação e potenciais hídricos negativos (>-0,4 MPa) reduziram a germinabilidade. O reduzido fornecimento hídrico é provavelmente o fator limitante para a germinação de sementes de bromélias na restinga de Maricá. As plântulas foram extremamente sensíveis às altas temperaturas e ao soterramento, não conseguindo emergir quando a profundidade excedeu $10 \mathrm{~mm}$. Sugere-se que a distribuição variável de chuvas, a baixa capacitância hídrica do solo e as altas temperaturas inibem a germinação e o estabelecimento de plântulas em condições de restinga. Conseqüentemente, as bromélias não parecem capazes de agir como pioneiras nas áreas entre moitas da restinga de Maricá.

Palavras-chave: plântula, crescimento, temperatura, restinga.

Artigo recebido em 07/2007. Aceito para publicação em 12/2007.

${ }^{1}$ Part of the $\mathrm{PhD}$ thesis from the first author.

${ }^{2}$ Author for correspondence: Instituto de Pesquisa Jardim Botânico do Rio de Janeiro, Rua Pacheco Leão 915, 22460-030, Rio de Janeiro, RJ, Brasil. andre@jbrj.gov.br

${ }^{3}$ Universidade Federal do Rio de Janeiro, Cidade Universitária, Centro de Ciências da Saúde, Bloco A, Instituto de Biologia, Departamento de Ecologia, sala A2 102, Laboratório de Ecologia de Comunidades, Ilha do Fundão, C.P. 68020, 21944-590, Rio de Janeiro, RJ, Brasil. rir@ biologia.ufrj.br 


\section{INTRODUÇÃO}

Much of the Brazilian coast is characterized by sandy plains called restingas (Araujo 1992), that support vegetation that ranges from halophytic herbs to forest. One of the most characteristic physiognomy consists of vegetation islands of various sizes $\left(<5\right.$ to $\left.>400 \mathrm{~m}^{2}\right)$ surrounded by bare sand. Environmental conditions outside the islands are hostile to plant establishment: soils are sandy, oligotrophic, hold little $\mathrm{H}_{2} \mathrm{O}$ and may exceed $60^{\circ} \mathrm{C}$ (Mantovani \& Rios 2001) making seed germination, seedling establishment and the consequent vegetation island initiation on bare sand difficult.

The islands are apparently initiated by pioneer species such as the geophytic palm Allagoptera arenaria (Gomes) Kuntze (Palmae) and later, the woody species Clusia hilariana Schtdl. (Clusiaceae) (Zaluar \& Scarano 2000). Because vegetation islands maintain better microclimatic conditions than the bare sand, pioneer plants in restinga habitat probably act as nurse plants (Franco et al. 1984; Franco \& Nobel 1989).

Hay et al. (1981) theorized that terrestrial bromeliads can act as pioneers and nurse plants in the restinga of Maricá. They are abundant both inside and outside the islands; can absorb water and nutrients through their leaves (Benzing 1990; Reinert et al. 1997) and soil below Neoregelia cruenta (R. Grah) L.B. $\mathrm{Sm}$., growing isolated in open areas of the restinga, contained more organic matter and displayed higher cation exchange capacity than adjacent barren soils (Hay \& Lacerda 1980). Thus, the presence of bromeliads would improve conditions for the later establishment of less tolerant plants on bare sand. However, young seedlings of terrestrial bromeliads rarely occur inside or outside the islands in restinga (Mantovani \& Rios 2001), although mature plants produce many seeds (Fischer \& Araujo 1995).

The rarity of bromeliad seedlings in the field suggests high mortality during the seed and/or seedling stages (see Mondragón et al. 1999). In this study, we assessed three terrestrial bromeliads for seed germinability, water balance and germination under different water potentials; susceptibility of seeds to high temperatures and desiccation; and susceptibility of young seedlings to high temperatures, desiccation and burial in sand. The goal of this study is to understand the apparent limitations for the establishment of bromeliads through seeds in the Brazilian restinga.

\section{Materials \& Methods \\ Studied site and plant species}

This study was carried out from December 1999 to May 2001 in the Restinga of Maricá, southeastern Brazil, Rio de Janeiro state (2253'S; 4252'W). Detailed information about structure, physiognomy and plant species of Maricá vegetation can be obtained in Araujo (1992) and Reinert et al. (1997). The study site consists of vegetation islands separated by bare sand (zone 3 sensu Araujo 1992). Epiphytic bromeliads such as Tillandsia usneoides (L.) L., T. stricta Sol. (Reinert et al. 1997) and terrestrial species such as Bilbergia amoena (Lodd.) Lindl., Bromelia antiachanta Bertol, Vriesia neoglutinosa Mez, Neoregelia cruenta, and Aechmea nudicaulis var. cuspidata (Baker) occur at Maricá (Silva \& Sommer 1984). Considering their high frequency and wide distribution in the restinga of Maricá, $V$. neoglutinosa, $N$. cruenta, and A. nudicaulis were chosen for this study (Fig. 1). These three species occur in three different microhabitats: inside, outside, and at the border of vegetation islands.

The macro-climate of Maricá is Aw (sensu Köppen's classification), characterized by a rainy and hot summer and a dry and warm winter (Mantovani \& Rios 2001). Mean monthly air temperature varies from 15.3 to $28.0^{\circ} \mathrm{C}$, but air temperatures as high as $40^{\circ} \mathrm{C}$ occur during summer. Mean annual air relative humidity is $81.7 \%$, and mean annual rainfall is $1130.8 \mathrm{~mm}$. Although the driest period is from May to October, periods of 30 consecutive, rain-free days, have been reported in January and February (Mantovani \& Rios 2001). 

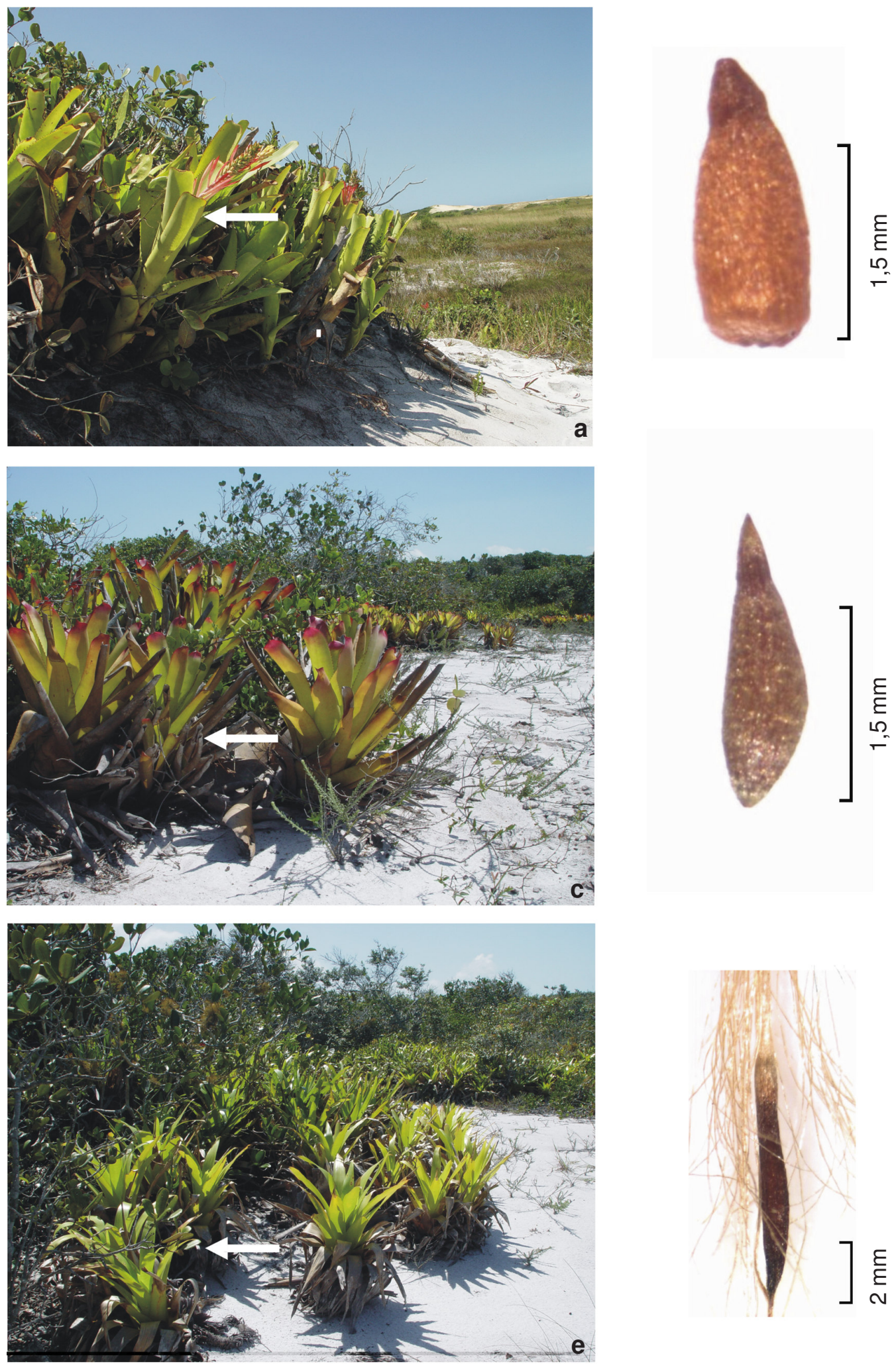

Figure 1 - Terrestrial bromeliads (arrows) at the border of vegetation islands in "restinga". Their respective seeds also are shown. a, b. Aechmea nudicaulis; c, d. Neoregelia cruenta; e, f. Vriesia neoglutinosa. 
Mantovani \& Rios (2001) provided data of abiotic soil conditions during a typical summer day in the study site. Within islands, temperatures at the soil surface and $5 \mathrm{~cm}$ below were always similar during the day, varying from 25 to $29^{\circ} \mathrm{C}$. Outside the islands, the surface temperature may surpass $60^{\circ} \mathrm{C}$ at noon during summer, while the mean temperature $5 \mathrm{~cm}$ below the soil surface is $40.7^{\circ} \mathrm{C}$. The mean soil water content at the surface within islands, during the day, varied between 18.2 to $27.3 \mathrm{mg} \mathrm{H}_{2} 0$ [g dw soil] $^{-1}$, and at $5 \mathrm{~cm}$ below the soil surface it varied from 21.2 to $40.6 \mathrm{mg} \mathrm{H}_{2} 0$ [g dw soil] ${ }^{-1}$. Mean soil water content was much lower outside the islands, decreasing at surface from 2.6 to 0.9 [g dw soil] $]^{-1}$ from 8 to $14 \mathrm{~h}$, while $5 \mathrm{~cm}$ below it decreased from 26 to 12.2 [g dw soill ${ }^{-1}$ at the same period.

We analyzed monthly rainfall and evaporation rates from 1989 to 2000 using the databank of the Brazilian National Institute of Meteorology (INMET). The total number of days per month with and without precipitation were also determined. The number of precipitation events constituded by just 1 or 2 , $3,4,5,6,7,8,9$ or 10 continguous rainy days were determined from 1993 to 2000 . We considered as rainy days those with precipitations $\geq 0.1 \mathrm{~mm}$ rainfall/day.

\section{Seeds collecting and processing}

Fruits from the bromeliad species were collected in the field at different times along 1999 to 2001, and the seeds were used for the germination studies after 1-2 days. The following experiments were conducted for the three bromeliad species studied. Unless otherwise stated, during all experiments below seeds (Fig. 1) were sown in closed Petri dishes on moist filter paper that were maintained under $3.5 \mu \mathrm{mol}^{2} \mathrm{~s}^{-1}$ of PAR. Seeds were considered germinated when the seedling emerged.

\section{Effect of temperature on seed germinability}

To determine if seeds from the three bromeliad species tolerate high temperatures, 36 open dishes (in order to avoid possible condensation) per species, with 8 to 11 seeds each sown on dried restinga sand, were stored in three incubators (12 dishes per treatment) under a $8 /$ 16 h daily temperature cycle of $35 / 27^{\circ} \mathrm{C} ; 50 / 27^{\circ} \mathrm{C}$ and $60 / 27^{\circ} \mathrm{C}$ during 30 days. Seeds were not watered during this period. Twenty open dishes per species, with 8 to 11 seeds each, were sown on dried restinga sand and maintained also without watering at $27^{\circ} \mathrm{C}$ for 30 days to serve as controls. After the 30 days, seeds from all treatments were washed in a $1: 1(\mathrm{v}: \mathrm{v})$ solution of sodium hypochloride:alcohol $70^{\circ}$, air dried for 5 min and sown on moist filter paper in closed Petri dishes as described above, to test for germination at $27^{\circ} \mathrm{C}$. The dishes were assessed daily and the final germination percentage were determined after 30 days of experiment.

\section{Effect of dry-wet cycles on seed germination}

The purpose of this experiment was to assess germination under shifting water availability, using dry-wet cycles of different durations (Baskin \& Baskin 1982; 1998). The minimum amount of water necessary to induce soil saturation under field capacity was determined for open Petri dishes (lids removed) filled with $12 \pm 0.001 \mathrm{~g}$ of dried restinga sand. The application of $1.5 \mathrm{ml}$ of distilled water quickly increased water content from $0 \mathrm{mg}$ of water [g dw soill] ${ }^{-1}$ (driest condition) to $125 \mathrm{mg}$ of water [ $\mathrm{g} \mathrm{dw}$ soil ${ }^{-1}$ (field capacity), and the water content was again $0 \mathrm{mg}$ of $\mathrm{H}_{2} 0$ [g dw soill $^{-1}$ after $24 \mathrm{~h}$ under laboratory conditions (see general methods above). The experiment proceeded in two steps. In step one, during 30 days, dishes with dried sand $(0 \mathrm{mg}$ of water [g dw soil] $]^{-1}$ ) and the 8 to 11 seeds (three dishes per irrigation treatment) were subjected to five irrigation treatments provided daily and once each $3,6,12,24$, and 30 days to simulate different wet/dry cycles. The dishes were assessed daily to note germination. The final germination percentage were determined after 30 days of experiment. In step two, which began immediately at the conclusion of step one, the objective was to determine if the nongerminated seeds of the step one were able 
to germinate under conditions of continuous water supply. In step two the nongerminated seeds from step one were washed and transferred to closed Petri dishes with moist filter paper and a continuous water supply under $27^{\circ} \mathrm{C}$ and $3.5 \mu \mathrm{mol}^{2} \mathrm{~s}^{-1}$ of PAR. The dishes were again assessed daily and the final germination percentage were determined after 30 days of experiment.

\section{Effect of water potential on germination}

This experiment assessed the response of bromeliad seeds to increasingly negative water potentials ( $\mathrm{y}=0.000$ (control), $-0.046,-0.141$, $-0.400,-0.900,-1.700$, and $-2.600 \mathrm{MPa}$ ), which were achieved by irrigation with solutions containing increasing amounts of polyethyleneglycol 6000 (PEG 6000) (Michael $\&$ Kaufmann 1972). For each solution six dishes with ten seeds each were kept continuously moist for 30 days at $27^{\circ} \mathrm{C}$ and $3.5 \mu \mathrm{mol}^{2} \mathrm{~s}^{-1}$ of PAR. Germination was assessed after 30 days.

\section{Seed hydration and dehydration curves}

The purpose of this experiment was to determine the dynamics of imbibition and loss of water by seeds. Twelve dishes lined with filter paper containing 50 seeds per dish of $N$. cruenta and of $A$. nudicaulis, and 20 seeds per dish of $V$. neoglutinosa, were maintained moist for $48 \mathrm{~h}$, a sufficient time for seeds to attain maximum saturation weight as revealed by previous analysis. During imbibition the seeds were removed from the wet filter paper, completely air dried and weighed to $0.0001 \mathrm{~g}$ using a precision balance, after which they were returned to the moist filter paper. Seeds were weighed every $2 \mathrm{~h}$ in the first $6 \mathrm{~h}$ of experiment (beginnig with hydration) and every $4 \mathrm{~h}$ during the last $42 \mathrm{~h}$. The weighing process took no more than four minutes, and the dryness of seed surface was observed using a stereomicroscope. After $48 \mathrm{~h}$, the seeds were air dried and transferred to empty dishes without water or sand. The 12 dishes for each species were separated in four groups of three dishes each. Each group were stored respectively at $27,35,50$, and $60^{\circ} \mathrm{C}$ in order to calculate dehydration versus increasing temperatures. Dehydration was calculated by the decrease in the relative water content of seeds after 1 , 2, 4, 6 and $8 \mathrm{~h}$ for each temperature treatment. Relative water content of seeds was calculated per dish as Mantovani (1999a):

$$
\mathrm{RWC}(\%)=((\mathrm{MFW}-\mathrm{DW}) \times 100) /(\mathrm{FW}-\mathrm{DW})
$$

where RWC $=$ relative water content of seeds, MFW = maximum fresh weight of seeds after $48 \mathrm{~h}$ of hydration, $\mathrm{DW}=$ constant dry weight of seeds after 3 days at $130^{\circ} \mathrm{C}$, and $\mathrm{FW}=$ fresh weight of seeds after $0,1,2,4,6$ and $8 \mathrm{~h}$ of dehydration.

\section{Response of seeds to short term desiccation}

Seeds dehydrated at $27,35,50$, and $60^{\circ} \mathrm{C}$ in the previous experiment were tested for germinability. After 1, 2, 4, 6, and $8 \mathrm{~h}$, four dishes (6 seeds each) for each temperature treatment were separated and allowed to cool under ambient laboratory conditions. They were tested for germinability at $27^{\circ} \mathrm{C}$ and $3.5 \mu \mathrm{mol}^{2} \mathrm{~s}^{-1}$ of PAR.

\section{Effect of temperature and moisture stress on seedling growth and survival}

After submission to stressful conditions, the time after which newly germinated seeds fail to recover when irrigated or returned to less stressful temperatures, is called "the point of no return" (Mohr \& Schopfer 1995). This point was determined for seeds subjected to drought and temperature stresses. Six days after germination, seedlings growing under laboratory conditions had a radicle, but no exposed cotyledon (Mantovani \& Rios 2005). After 14 days the cotyledonary groove had opened, and the first new leaf began to expand. Six days after germination, seedlings were placed on $10 \mathrm{~g}$ of dried restinga sand in open Petri dishes (lids removed) and subjected to four temperature regimes: continuously at $27^{\circ} \mathrm{C}$; and at a $8 / 16$ h daily cycle of $35 / 27,50 /$ 27 and $60 / 27^{\circ} \mathrm{C}$. The young seedlings were not watered during the experiment. Thirty six 
dishes (9 seedlings each) were prepared for each temperature treatment. After 1, 2, 3, 4, 5, $10,15,20$ and 30 days at each temperature, one dish per treatment was separated and a continuous water supply provided for its 9 seedlings. The survival of the seedlings was expressed as the percentage of those which were able to completely extrude the plumule.

\section{Response of seedlings to burial in sand}

Seedlings of $N$. cruenta and $A$. nudicaulis (with radicle and plumule) and $V$. neoglutinosa (only with plumule; Mantovani \& Iglesias 2005) approximately $5 \mathrm{~mm}$ in length were buried in sand under laboratory conditions. Glass tubes $80 \mathrm{~mm}$ long and $20 \mathrm{~mm}$ wide were filled with restinga sand, and seedlings buried to depths of 10, 25 and $50 \mathrm{~mm}$. Five tubes (with 10 seedlings in each tube) were prepared per depth. The controls was represented by five tubes with nonburied seedlings (with 10 seedlings per tube). All tubes were watered daily. After 30 days, seedlings which had emerged above the surface were counted. Non-emerging seedlings were removed from the sand and their lenght measured using a stereomicroscope equipped with an ocular micrometer.

\section{Statistical analysis}

In all the experiments a completly randomised design was used. For comparisons between two samples with non-normal distribution the Mann-Whitney test was applied (rainfall versus evaporation). For comparisons among three or more samples the one-Way ANOVA and the Kruskal-Wallis tests were applied for normally (experiments 1 and 3 ) and non-normally (experiment 7) distributed data, respectively. In order to detect a two factor (temperature and time) interaction on seed germination, a bifactorial ANOVA was performed (experiment 5). Differences were detected when $\mathrm{P} \leq 0.05$. The percentage data were arcsine transformed previously to statistical analysis (Zar 1996; Santana \& Ranal 2004).

\section{Results \\ Rainfall}

The mean monthly rainfall from 1989 to 2000 for the restinga of Maricá was $98.3 \pm 57.5 \mathrm{~mm}$ (Fig. 2), significantly lower than the mean monthly evaporative rates of $124.5 \pm 27.6 \mathrm{~mm}(\mathrm{P}<0.0001)$. Even considering precipitations of just $0.1 \mathrm{~mm}$ rainfall/day, the number of days per month without precipitation $(21 \pm 3)$ were significantly higher $(\mathrm{P}<0.0001)$ than rainy days $(9 \pm 3)$. For the restinga of Maricá, from 1993 to 2000, 144 precipitation events lasted just one day of rain. For the same period, 97 precipitation events were constituted by two contiguous rainy days and 4 events were constituted by 7 contiguous rainy days. Only on a single occasion from 1993 to 2000 rained consecutively for 10 days with daily delivery from 0.2 to $50 \mathrm{~mm}$, with a total of 150 $\mathrm{mm}$. The longest dry period for the restinga of Maricá occurred in January and February of 1994: 28 contiguous days without any rain.

\section{Effect of temperature on seed germinability}

The percentage of seeds that germinate at $27^{\circ} \mathrm{C}$ was $82-99 \%$ for $V$. neoglutinosa, $N$. cruenta, and A. nudicaulis (Table 1). Germination rates were similar at $35 / 27^{\circ} \mathrm{C}$ or $50 / 27^{\circ} \mathrm{C}$, but reduced at $60 / 27^{\circ} \mathrm{C}$ treatment $(\mathrm{P}<0.05)$ to $72-$ $88 \%$. All seeds germinated in 3 to 5 days after watering started. Thus, fresh seeds of all three bromeliads are nondormant and were little affected by soil temperatures ranging from 27 to $50^{\circ} \mathrm{C}$.

\section{Effect of dry-wet cycles on seed germination}

In step one, except for $V$. neoglutinosa seeds, which germinated to $56 \%$ when watered once every 3 days, seeds germinated only when water was provided every day (Table 2). Daily watering induced the seeds of $V$. neoglutinosa, $N$. cruenta and A. nudicaulis to germinate after 12,14 , and 19 days, respectively. When watered ever third days, V. neoglutinosa seeds germinated after 23 days. In step two, the nongerminated seeds from step one of all three species germinated to $81-100 \%$ when transferred to closed Petri dishes 


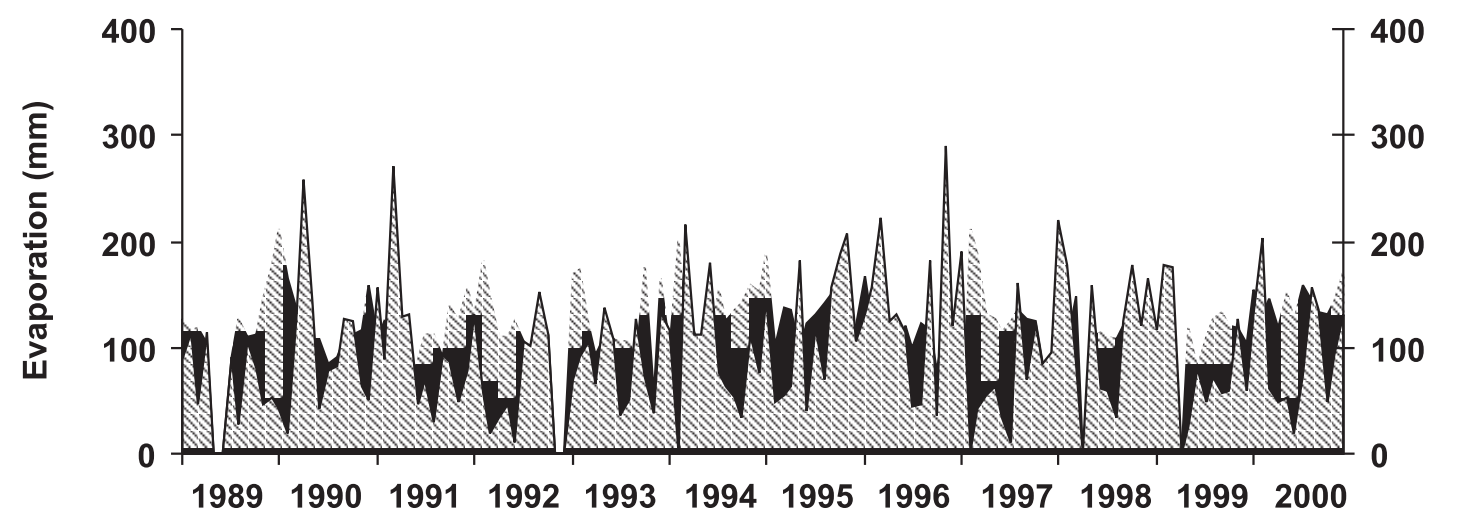

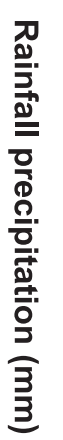

Years

a

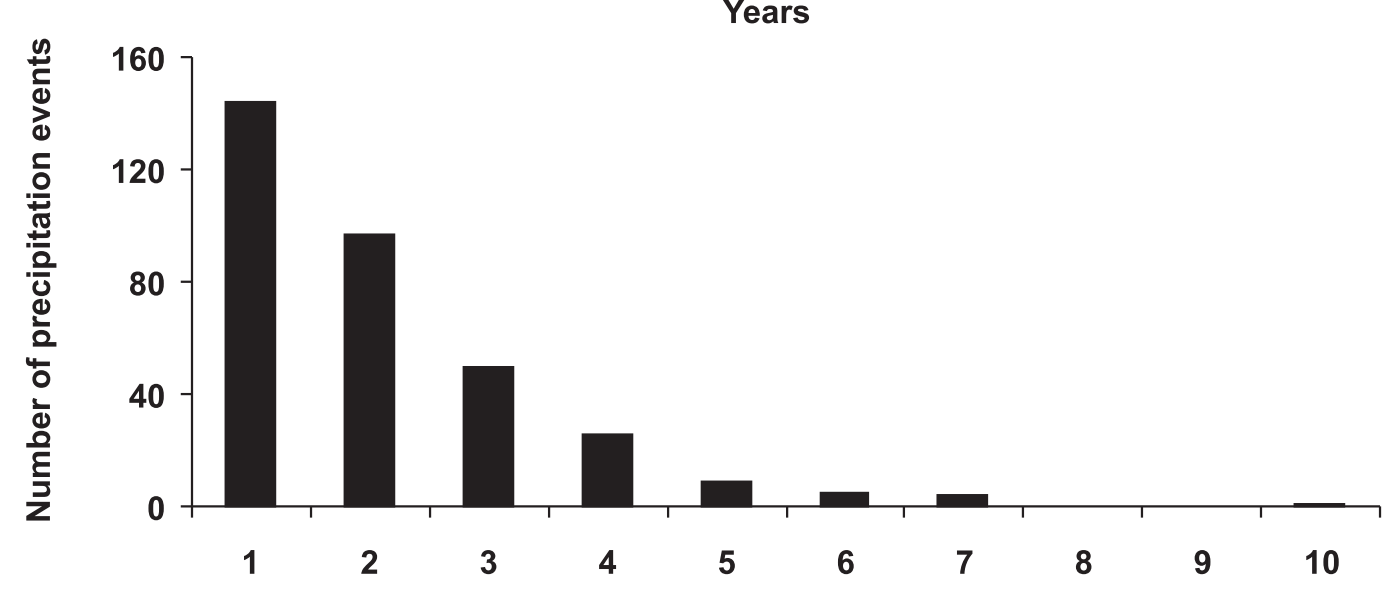

Number of contiguous rainy days

Figure 2 - Evaporation and rainfall precipitation dynamics for the restinga of Maricá. a. Comparison of evaporation (gray) and rainfall precipitation levels (black). b. Number of precipitation events constituted by 1 or 2-10 contiguous rainy days. Note that 144 precipitation events lasted just one rainy day. Only on a single occasion from 1993 to 2000 rained consecutively for 10 days (arrow).

with a continuous supply of water. In the dry-wet cycle from the step one, receiving $125 \mathrm{mg}$ of $\mathrm{H}_{2} 0$ [g dw soil $]^{-1}$ daily, the bromeliads seeds needed at least 12-19 days to germinate.

\section{Effect of water potential on germination}

Seeds of $V$. neoglutinosa, $N$. cruenta and A. nudicaulis germinated only when they were incubated with water or on PEG solutions of $\mathrm{y}=-0.04$ and $-0.14 \mathrm{MPa}$ (Table 3).

\section{Seed hydration and dehydration curves \\ Seeds of the three species had similar patterns} of hydration and dehydration (Fig. 3 a-f). Seeds reached $100 \%$ of RWC after $48 \mathrm{~h}$. However when dehydrated for $1 \mathrm{~h}$ at 27,35, 50, and $60^{\circ} \mathrm{C}$, RWC decreased to $76,58,16$, and $10 \%$, respectively, for $V$. neoglutinosa, 75, 71, 37, and $19 \%$ for $N$. cruenta and $65,58,20$, and $10 \%$ for A. nudicaulis.

\section{Response of seeds to short term desiccation}

Dehydration at $27,35,50$, and $60^{\circ} \mathrm{C}$ did not prevented germination, as mean percentage germination for all three species ranged between 70 and 100\% (Table 4). There were no significant interactions between temperature 
Table 1 - Effect of temperature on seed germinability. Percentage (mean \pm standard deviation, $\mathrm{n}=12$ ) germination of seeds of $V$. neoglutinosa, $N$. cruenta and A. nudicaulis stored at different temperatures after 30 days. Different superscripts indicate significant differences within a species $(\mathrm{p}<0.05)$.

\begin{tabular}{lcccc}
\hline \multicolumn{1}{c}{ Species } & $\mathbf{2 7} \mathbf{7}^{\circ} \mathbf{C}$ & $\mathbf{3 5}^{\circ} \mathbf{C}$ & $\mathbf{5 0}^{\circ} \mathbf{C}$ & $\mathbf{6 0}^{\circ} \mathbf{C}$ \\
\hline V. neoglutinosa & $82.3 \pm 19.8^{\mathrm{a}}$ & $86.8 \pm 11.7^{\mathrm{a}}$ & $83.5 \pm 11.6^{\mathrm{a}}$ & $72.3 \pm 11.6^{\mathrm{b}}$ \\
N. cruenta & $98.2 \pm 4.1^{\mathrm{a}}$ & $98.3 \pm 3.8^{\mathrm{a}}$ & $95.8 \pm 6.7^{\mathrm{a}}$ & $89.6 \pm 12.7^{\mathrm{b}}$ \\
A. nudicaulis & $99.1 \pm 2.8^{\mathrm{a}}$ & $100.0^{\mathrm{a}}$ & $99.0 \pm 3.2^{\mathrm{a}}$ & $88.8 \pm 11.7^{\mathrm{b}}$ \\
\hline
\end{tabular}

Table 2 - Effect of dry-wet cycles on seed germination. Percentage (mean \pm standard deviation, $\mathrm{n}=3$ ) seed germination of $V$. neoglutinosa, $N$. cruenta and A. nudicaulis subjected to different dry-wet cycles. Step 1: Germination of seeds during the first 30 days of the experiment. Step 2: Germination of seeds that failed to germinate during the first 30 days of Step 1 that subsequently were placed under continuous water supply. na $=$ not applicable.

\begin{tabular}{lcccccc}
\hline STEP 1 & \multicolumn{5}{c}{$\begin{array}{c}\text { Germination under dry-wet cycles during 30 days } \\
\text { Wetted once every }\end{array}$} \\
\hline & Daily & $\mathbf{3}$ days & 6 days & $\mathbf{1 2}$ days & $\mathbf{2 4}$ days & $\mathbf{3 0}$ days \\
\hline V. neoglutinosa & $78.4 \pm 8.7$ & $56.5 \pm 11.5$ & 0 & 0 & 0 & 0 \\
$N$. cruenta & $23.7 \pm 10.9$ & 0 & 0 & 0 & 0 & 0 \\
A. nudicaulis & $14.4 \pm 17.1$ & 0 & 0 & 0 & 0 & 0 \\
\hline STEP 2 & \multicolumn{7}{c}{ Germination under continuous } & water after 30 days \\
\hline V. neoglutinosa & na & na & $89.2 \pm .0 .6$ & $92.6 \pm 0.6$ & $93.3 \pm 5.7$ & $86.6 \pm 6.7$ \\
N. cruenta & na & $89.4 \pm 1.7$ & 100.0 & $93.3 \pm 11.5$ & 100.0 & $90.0 \pm 17.3$ \\
A. nudicaulis & na & $86.6 \pm 4.7$ & $87.3 \pm 3$ & 100.0 & 100.0 & $81.8 \pm 19.2$ \\
\hline
\end{tabular}

Table 3 - Effect of water potential on germination. Percentage (mean $\pm \mathrm{sd}, \mathrm{n}=6$ ) seed germination of $V$. neoglutinosa, $N$. cruenta and A. nudicaulis at a range of water potentials after 30 days. Different superscripts represent significant differences between treatments within a species $(\mathrm{p}<0.05)$

\begin{tabular}{lccccccc}
\hline Species & \multicolumn{7}{c}{ Water potential of PEG 6000 solutions } \\
\hline & Water & $\mathbf{- 0 . 0 4 M P a}$ & $\mathbf{- 0 . 1 4} \mathbf{M P a}$ & $\mathbf{- 0 . 4} \mathbf{M P a}$ & $\mathbf{- 0 . 9} \mathbf{M P a}$ & $\mathbf{- 1 . 7} \mathbf{M P a}$ & $\mathbf{- 2 . 6 M P a}$ \\
\hline V. neoglutinosa & $98.0 \pm 4.4^{\mathrm{a}}$ & $82.0 \pm 13.0^{\mathrm{b}}$ & $82.0 \pm 14.0^{\mathrm{b}}$ & 0.0 & 0.0 & 0.0 & 0.0 \\
N. cruenta & $100.0^{\mathrm{a}}$ & $83.0 \pm 14.3^{\mathrm{b}}$ & $79.3 \pm 11.6^{\mathrm{b}}$ & 0.0 & 0.0 & 0.0 & 0.0 \\
A. nudicaulis & $98.3 \pm 4.0^{\mathrm{a}}$ & $82.9 \pm 8.3^{\mathrm{b}}$ & $65.0 \pm 20.7^{\mathrm{b}}$ & 0.0 & 0.0 & 0.0 & 0.0 \\
\hline
\end{tabular}



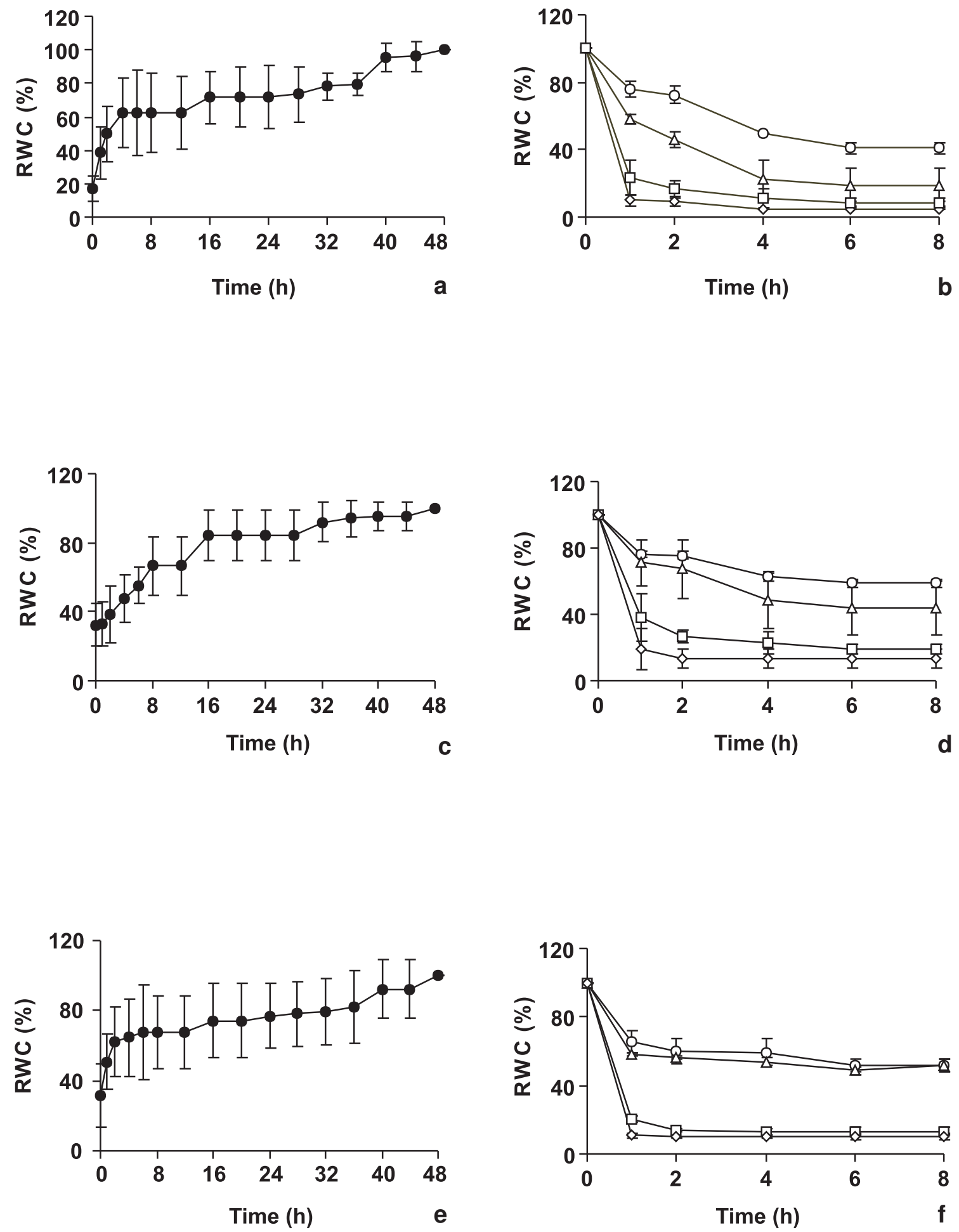

Figure 3 - Seed hydration and dehydration curves. Hydration (a, c, e) and dehydration (b, d, f) curves for seeds of $V$. neoglutinosa $(\mathrm{a}, \mathrm{b}), N$. cruenta $(\mathrm{c}, \mathrm{d})$, and $A$. nudicaulis $(\mathrm{e}, \mathrm{f})$ seeds $(\mathrm{n}=12$ for $N$. cruenta and $A$. nudicaulis; $\mathrm{n}=20$ for $V$. neoglutinosa). Symbols indicate temperatures of $27^{\circ} \mathrm{C}(\bigcirc), 35^{\circ} \mathrm{C}(\triangle), 50^{\circ} \mathrm{C}(\square), 60^{\circ} \mathrm{C}(\diamond)$. 
and time on seed germination for any of the studied species as revealed by factorial analysis $(\mathrm{P}>0.05)$. Significant results $(\mathrm{P}<0.05)$ in factorial analysis were only founded for the factor temperature for the three species.

\section{Effect of temperature and moisture stress on seedling growth and survival}

Seedlings were quite sensitive to dehydration and high temperature (Fig. 4). Between $60-100 \%$ of the seedlings of $V$. neoglutinosa survived 3 days of drying at 27 and $35 / 27^{\circ} \mathrm{C}$, but survival decreased to only $10 \%$ for seedlings subjected $10-30$ days to the higher temperatures of treatment. At $50 / 27^{\circ} \mathrm{C}$, $50 \%$ of the seedlings survived until the second day, but after the third day no seedling survived. At $60 / 27^{\circ} \mathrm{C}$, just one day of treatment was enough to kill all seedlings of $V$. neoglutionosa.

For N. cruenta, 22 and $38 \%$ of the seedlings were alive at 27 and $35 / 27^{\circ} \mathrm{C}$, respectively, after 10 days of treatment, but after 20 days there were no survivors. Seedlings of $A$. nudicaulis had higher survival capacity under lower temperatures than the other two species. At 27 and $35 / 27^{\circ} \mathrm{C}$, 88 and $22 \%$ of the A. nudicaulis seedlings were still alive after 15 days of drying treatment, while at $27^{\circ} \mathrm{C}, 33 \%$ of them survived 30 days. After 30 days at $35 / 27^{\circ} \mathrm{C}$, none of the seedlings was alive. Only 1 day of treatment at 50/27 and $60 / 27^{\circ} \mathrm{C}$ were sufficient to kill all of the seedlings of $N$. cruenta and A. nudicaulis.

\section{Response of seedlings to burial in sand}

The seedlings of $V$. neoglutinosa, $N$. cruenta and $A$. nudicaulis exhibited little capacity to emerge from burial (Fig. 5). After 30 days, only 2 and $4 \%$ of the seedlings of $N$. cruenta and $A$. nudicaulis, respectively, had appeared at the soil surface from a depth of $10 \mathrm{~mm}$, while no seedlings of $V$. neoglutinosa had emerged. No seedling had emerged from greater depths. Seedling height was similar for all treatments $(\mathrm{P}>0.05)$ : 3.1-4.8 $\mathrm{mm}$ for $V$. neoglutinosa, 5-6.3 $\mathrm{mm}$ for $N$. cruenta and 9-11 $\mathrm{mm}$ for A. nudicaulis. Although similar in size, the morphology of the buried seedlings of $N$. cruenta and $A$. nudicaulis was different from that of the non-buried seedlings. Buried seedlings were etiolated with a long epicotyl but only one or two small leaves at the apices, while in non-buried seedlings the epicotyl was short and two more expanded leaves were presented.

Table 4 - Response of seeds to short term desiccation. Percentage germination (mean \pm standard deviation, $\mathrm{n}=4$ ) of seeds $V$. neoglutinosa; $N$. cruenta e A. nudicaulis subjected to dehydration at $27,35,50$, and $60^{\circ} \mathrm{C}$ for $1,2,4,6$ and $8 \mathrm{~h}$.

\begin{tabular}{|c|c|c|c|c|c|c|}
\hline & \multirow{2}{*}{$\begin{array}{l}\text { Temperature of } \\
\text { desiccation }\left({ }^{\circ} \mathbf{C}\right)\end{array}$} & \multicolumn{5}{|c|}{ Time } \\
\hline & & 1h & $2 \mathrm{~h}$ & $4 h$ & $6 \mathrm{~h}$ & $8 \mathrm{~h}$ \\
\hline 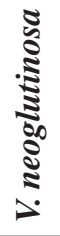 & $\begin{array}{l}27 \\
35 \\
50 \\
60\end{array}$ & $\begin{array}{c}93.3 \pm 11.0 \\
100.0 \\
94.4 \pm 9.6 \\
75.5 \pm 7.6\end{array}$ & $\begin{array}{c}100.0 \\
86.6 \pm 23.0 \\
85.0 \pm 13.2 \\
64.4 \pm 3.8\end{array}$ & $\begin{array}{l}86.6 \pm 11.0 \\
94.4 \pm 9.6 \\
66.6 \pm 23.0 \\
86.6 \pm 23.0\end{array}$ & $\begin{array}{c}93.3 \pm 11.0 \\
80.0 \pm 34.6 \\
74.4 \pm 12.6 \\
76.6 \pm 8.8\end{array}$ & $\begin{array}{c}100.0 \\
93.3 \pm 11.0 \\
78.3 \pm 28.0 \\
66.6 \pm 11.5\end{array}$ \\
\hline 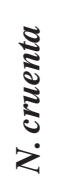 & $\begin{array}{l}27 \\
35 \\
50 \\
60\end{array}$ & $\begin{array}{c}87.7 \pm 10.7 \\
100.0 \\
85.7 \pm 14.2 \\
80.0\end{array}$ & $\begin{array}{c}93.3 \pm 11.5 \\
86.6 \pm 11.5 \\
80.0 \\
70 \pm 14.1\end{array}$ & $\begin{array}{l}95.2 \pm 8.2 \\
93.3 \pm 11.5 \\
82.2 \pm 16.7 \\
91.6 \pm 14.4\end{array}$ & $\begin{array}{c}100.0 \\
93.3 \pm 11.5 \\
91.6 \pm 14.4 \\
81.1 \pm 1.9\end{array}$ & $\begin{array}{c}90.4 \pm 8.2 \\
100.0 \\
88.8 \pm 19.2 \\
93.3 \pm 11.5\end{array}$ \\
\hline 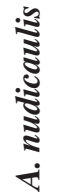 & $\begin{array}{l}27 \\
35 \\
50 \\
60\end{array}$ & $\begin{array}{c}94.4 \pm 9.6 \\
100.0 \\
80.0 \pm 20.0 \\
90.0 \pm 14.1\end{array}$ & $\begin{array}{l}86.6 \pm 11.5 \\
94.4 \pm 9.6 \\
94.4 \pm 9.6 \\
92.3 \pm 11.5\end{array}$ & $\begin{array}{c}100.0 \\
81.9 \pm 3.2 \\
81.9 \pm 3.2 \\
80.0 \pm 34.6\end{array}$ & $\begin{array}{c}86.6 \pm 11.5 \\
93.3 \pm 11.5 \\
86.6 \pm 11.5 \\
80.0\end{array}$ & $\begin{array}{c}80.0 \\
100.0 \\
76.6 \pm 25.1 \\
100.0\end{array}$ \\
\hline
\end{tabular}



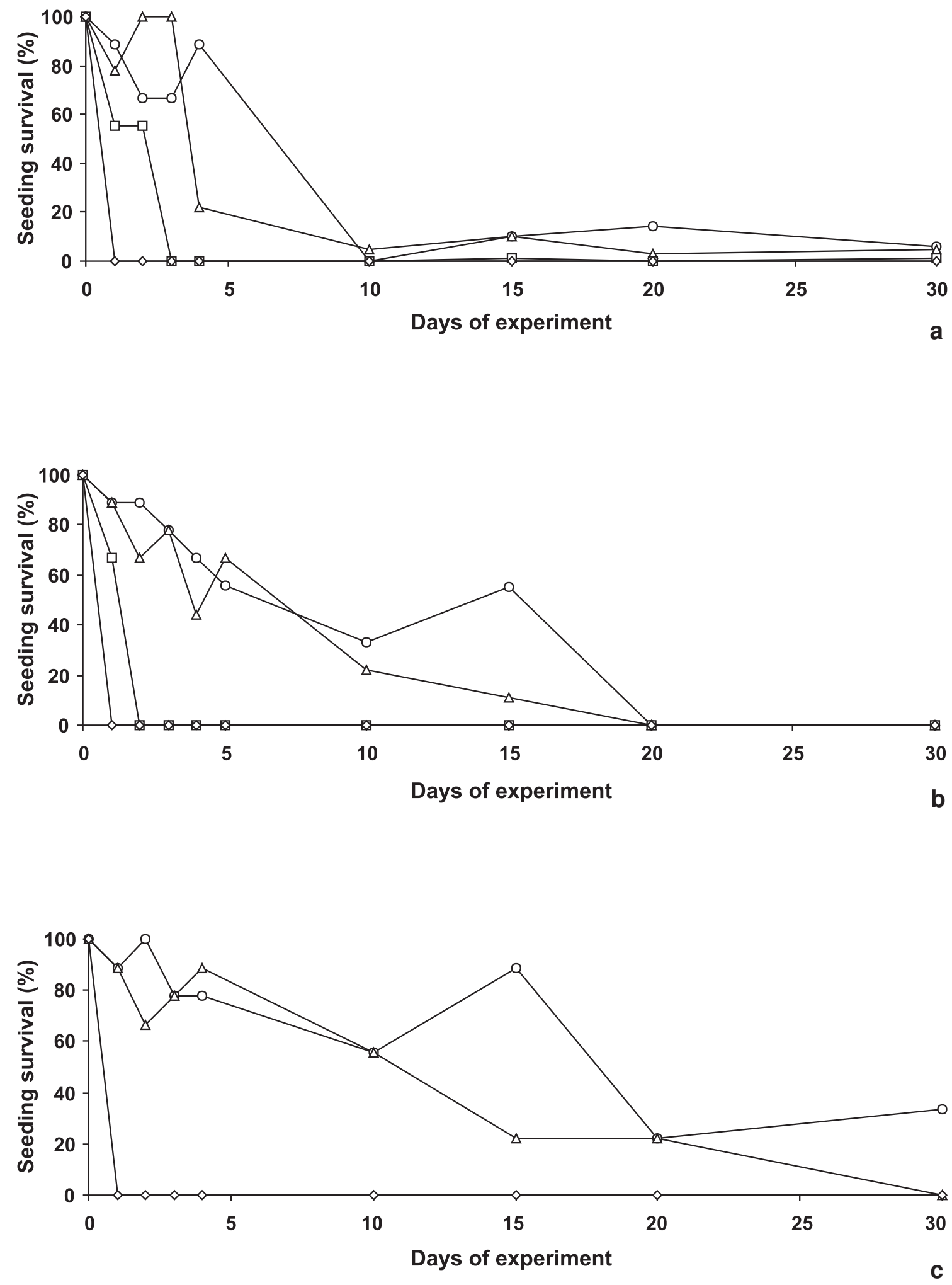

Figure 4 - Percentage of seedlings of $V$. neoglutinosa (a), N. cruenta (b) and A. nudicaulis (c) that survived under different temperatures. $27(\bigcirc), 35 / 27^{\circ} \mathrm{C}(\triangle), 50 / 27(\square)$ and $60 / 27^{\circ} \mathrm{C}(\diamond) .(\mathrm{n}=36)$ 

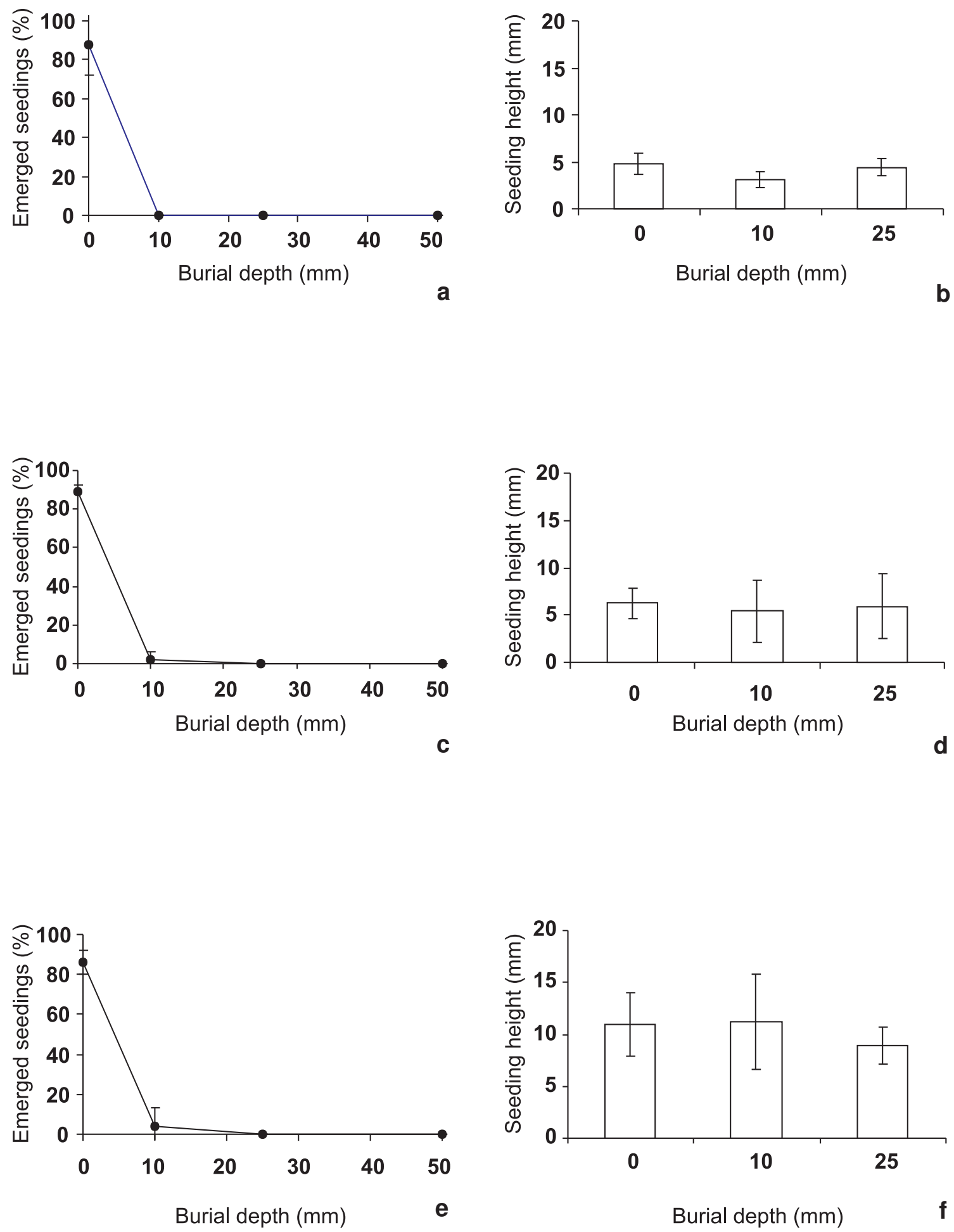

Figure 5-Percentage emergence and final height of seedlings of $V$. neoglutinosa (a, b), N. cruenta (c, d), and A. nudicaulis $(e, f)$ not buried $(0 \mathrm{~mm})$ and after burial at a depth of $10 ; 25$ and $50 \mathrm{~mm}$ in sand $(\mathrm{n}=5)$. 


\section{Discussion}

The germination of nondormant seeds of Vriesia neoglutinosa, Neoregelia cruenta and Aechmea nudicaulis was not completely inhibited by temperature or short term desiccation. Pinheiro \& Borghetti (2003) found in the restinga of Presidente Kennedy, Espirito Santo, Brasil that no germination of $A$. nudicaulis seeds was detected at $20 / 50^{\circ} \mathrm{C}$ (16/8 h). However, the maximum soil temperature at open areas of the restinga of Presidente Kennedy was around $46^{\circ} \mathrm{C}$ when exposed to full sunlight. Seed germinability of the species studied here, including A. nudicaulis, was significantly but little reduced (seed germinability $>70 \%)$ by higher temperatures $\left(60^{\circ} \mathrm{C}\right)$. This fact could be related to soil temperatures at the study site. Mantovani \& Rios (2001) stated that maximum soil temperatures at restinga of Maricá may exceed $60^{\circ} \mathrm{C}$ when exposed to full sunlight. Variation in temperature requirements for seed germination at an intraspecific level may be (Propert et al. 1985; Mayer et al. 1997) or not (Ellison 2001) correlated with climatic variables of collection sites. Further research is needed to enhance our knowledge on this subject for terrestrial bromeliads.

Although temperature had minor effects on seed germination of the studied bromeliads, prolonged drought did inhibit their germination. In dry-wet cycle (experiment 2), germination only occurred after 12 to 19 consecutive days of watering with $125 \mathrm{mg}$ of water [g dw soill $]^{-1}$. Even during the summer rainy season, the mean soil water content of the sandy restinga soil is often much lower than the necessary for germination under experimental conditions, varying from 0.9 to $40.6 \mathrm{mg}$ of water [ $\mathrm{g} \mathrm{dw}$ soill $^{-1}$ (Mantovani \& Rios 2001). Moreover, only once time during 1993-2000, did rain fall 10 days consecutively, suggesting that water availability in the field is most often below that necessary for germination.

The sensitivity of seeds to drought is further demonstrated by the results of experiment 3 . There was no germination at water potentials below $-0.14 \mathrm{MPa}$. The difference in water potential between a seed and the surrounding soil influences its hydration and germination (Kaufmann \& Ross 1970; Simon \& Mills 1982; Facelli \& Ladd 1996). Our results shows that seeds of these three bromeliads need to be continuously moist to germinate, which is supported by empirical observations made by bromeliad horticulturists (Rutledge \& Kendall 1989; Reilly 1991; Oeser 1991) and experimental results (Benzing 1978; Castro-Hernandez et al. 1999). However, the data from experiment 4 suggest that the need for continuous water can be caused by a high rate of water loss from bromeliad seeds, which produces an imbalance between water absorption and loss from the seeds.

A positive balance between water absorption and loss must occur for seeds to germinate (Harper $\&$ Benton 1966). The amount of water absorbed by a seed can be limited by a poor contact between the seed and adjacent soil particles (Simon \& Mills 1982). Seeds of N. cruenta and A. nudicaulis are about $2 \mathrm{~mm}$ in length, while the cylindrical seed of $V$. neoglutinosa reaches a diameter of $1 \mathrm{~mm}$ and a length of $4 \mathrm{~mm}$ (Fig. 1). These dimensions are similar to those of sand particles (Rowell 1994), which results in a lower degree of seed-soil contact for these bromeliad seeds. The high macro-porosity levels of restinga sandy soils would expose a great part of each bromeliad seed to the soil atmosphere, promoting seed water loss (Pérez-Fernandez et al. 2000), especially in restinga where soil temperatures reach $50-60^{\circ} \mathrm{C}$ (Mantovani \& Rios 2001). Rapid seed dehydration, in addition to a precipitation/evaporation ratio $<1$, sporadic precipitation, and the high porosity of restinga soils (Hay \& Lacerda 1984) can impose a low soil water availability and lead to a "water imbalance" within bromeliad seeds. These hypotheses are supported by the results experiments 1 and 3. When stored in closed Petri dishes (experiment 1) under continuous water supply, seeds began to germinate after 3 days, but germination under a daily dry-wet cycle required 12-19 days.

The seedlings of the three bromeliads were comparatively more sensitive to temperature and desiccation than their seeds (experiment 6). The results show that seeds are sensitive to stressful conditions during the radicle-emergence phase. In this sense, establishment in the barren 
inter-island areas require seeds to be in safe sites, buried below the soil surface, insulated from high temperatures and desiccation.

The ability of a seedling to emerge from the soil tends to relate to seed size (Foster \& Janson 1985; Leishman \& Westoby 1994). Large seed size correlates with extensive reserves and/or high seed weight. Seedlings originating from large seeds enter deeply into soils, or they can emerge from greater depths than can those from small seeds (Maun 1994). Capacity to emerge following deep burial is an adaptation to soils with high surface temperatures, high water deficits, or high instability (Maun 1994). Seed size varies from $10^{-6} \mathrm{~g}$ in orchids (Benzing 1981) to $10^{4} \mathrm{~g}$ in some palm seeds (Leishman et al. 1995). The seeds studied here weighed 5 to $6 \times 10^{-4} \mathrm{~g}$ (Mantovani 2002). Considering seed weight as an indicator of reserves for seedling growth, the bromeliad seeds have modest reserves compared to other plant life forms such as trees and shrubs (Foster \& Johnson 1985; Rockwood 1985). The final height of the buried bromeliad seedlings varied from only 0.6 to $1 \mathrm{~cm}$ after 30 days of growing (experiment 7). It is concluded therefore that seedlings from bromeliad seeds buried in the soil as per this study do not have sufficient reserves to allow the shoot to reach the surface. On the other hand, if the seeds germinate on the soil surface outside the islands, the seedling will not survive the high temperatures and desiccation.

Vriesia neoglutinosa, N. cruenta, and A. nudicaulis also occur as epiphytes in adjacent forest inland from restingas (Lacerda \& Hay 1992; Wendt 1997; Fontoura 2001). The same morphological and physiological adaptations that facilitate the establishment of epiphytes (Benzing 1986; Mantovani 1999a, b; 2000), probably also permit epiphytic bromeliads to occur as terrestrial plants in some microsites on restinga soils. However, as in the canopy, where the vertical distribution of bromeliads varies along distinct microsites (Benzing 2000; Fontoura 2001), the same is probably occurring in the case of the restinga island vegetation. The propagation of the epiphytic bromeliads through seeds in restinga habitat is probably limited to ameliorated microsites such as those within and at the periphery of vegetation islands (Mantovani \& Rios 2001) where chances of establishment and survival are higher (see Zotz 1997 for similar phenomenon in canopies). Zaluar \& Scarano (2000) and Freitas et al. (2000) stated that this is the most common pattern of the bromeliad distribution in restingas.

We conclude that bromeliads are not able to act as pioneer plants through germination outside the islands that characterize the restinga of Maricá. The main limitations are: rapid seed dehydration in addition to climate and soil conditions imposing a water imbalance antagonistic for seed germination and high sensitivity of seedlings to stressful conditions during the radicle-emergence phase.

\section{ACKNOWLEDGMents}

The authors are very grateful to Drs. Carol Baskin; Jerry Baskin and Dr. Marli Ranal for valuable help with the manuscript revision. We also thank Dr. Fabio R. Scarano, Ricardo Cardoso Vieira, Dulce Mantuano and Mr. Dutch Vandervort for discussion of ideas, encouragement and help with the English translation. Drs. Márcia and Rogério Margis; Mrs. Luis Frade, Sérgio Schubart, Itamar Macedo and Dr. Maulori helped for laboratory facilities and material. The first author was sponsored by CAPES.

\section{REFERENCES}

Araujo, D. S. D. 1992. Vegetation types of sandy coastal plains of tropical Brazil: a first approximation. In: Seelinger, U. (ed.). Coastal plant communities of Latin America. Vol 21. Academic Press Inc., San Diego, 337-347.

Baskin, J. M. \& Baskin, C. C. 1982. Effects of wetting and drying cycles on the germination of seeds of Cyperus inflexus. Ecology 63: 248-252.

Baskin, C. C. \& Baskin, J. M. 1998. Seeds: Ecology, Biogeography, and Evolution of Dormancy and Germination. Academic Press, San Diego, 666pp. 
Benzing, D. H. 1978. Germination and early establishment of Tillandsia circinnata Schlecht. (Bromeliaceae) on some of its hosts and other supports in southern Florida. Selbyana 5: 95-106. 1981. Why Orchidaceae is so large, its seeds so small, and its seedlings mycotrophic? Selbyana 5: 241-242.

. 1986. The vegetative basis of vascular epiphytism. Selbyana 9: 23-43. . 1990. Vascular epiphytes: general biology and related biota. Cambridge University Press, New York, 353p. 2000. Bromeliaceae: profile of an adaptive radiation. Cambridge University Press, Cambridge, 690p.

Castro-Hernandez, J. C.; Wolf, J. H. D.; GarciaFranco, J. G. \& González-Espinosa, M. 1999. The influence of humidity, nutrients and light establishment of the epiphytic bromeliad Tillandsia guatemalensis in the highlands of Chiapas, Mexico. Revista de Biologia Tropical. 47: 763-773.

Ellison, A . M. 2001. Interspecific and intraspecific variation in seed size and germination requirements of Sarracenia (Sarraceniaceae). American Journal of Botany 88(3): 429-437.

Facelli, J. M. \& Ladd, B. 1996. Germination requirements and responses to leaf litter of four species of eucalypt. Oecologia 107:441-445.

Fisher, E. A. \& Araujo, A. C. 1995. Spatial organization of a bromeliad community in the Atlantic rainforest, south-eastern Brazil. Journal of Tropical Ecology 11: 559-567.

Fontoura, T. 2001. Bromeliaceae and other epiphytes: stratification and other resources available to animals at the Jacarepiá State Ecological Reserve in Rio de Janeiro. Bromelia 6: 33-39.

Foster, S. A. \& Janson, C. H. 1985. The relationship between seed size and establishment conditions in tropical woody plants. Ecology 66: 773-780.

Franco, A. C. \& Nobel, P. S. 1989. Effect of nurse plants on the microhabitat and growth of cacti. Journal of Ecology 77: 870-886.

Franco, A. C.; Valeriano, D. M.; Santos, F. M.; Hay, J. D.; Henriques, R. P. B. \& Medeiros, R. A.
1984. Os microclimas das zonas de vegetação de praia da restinga de Barra de Maricá, Rio de Janeiro. In: Lacerda, L. D.; Araujo, D. S. D.; Cerqueira, R. \& Turcq, B. (eds.). Restingas; origens, estruturas e processos. CEUFF, Rio de Janeiro. Pp 413-423.

Freitas, A. F. N.; Cogliatti-Carvalho, L.; Sluys, M \& Rocha, C. F. D. 2000. Distribuição espacial de bromeliáceas na restinga de Jurubatiba, Macaé, RJ. Acta Botanica Brasilica 14: 175-180.

Harper, J.L. \& Benton, R. A. 1966. The behaviour of seeds in soil. II. The germination of seeds on the surface of a water supplying substrate. Journal of Ecology 54: 151-166.

Hay, J. D.; Lacerda, L. D. \& Tan, A. L. 1981. Soil cation increase in a tropical sand dune ecosystem due to a terrestrial bromeliad. Ecology 62: 1392-1395.

Hay, J. D. \& Lacerda, L. D. 1980. Alterações nas características do solo após fixação de Neoregelia cruenta (R. Grah.) L.B. Smith (Bromeliaceae) em um ecossistema de restinga. Ciência \& Cultura 32: 863-867.

Kaufmann, M. R. \& Ross, K. J. 1970. Water potential, temperature and kinetin effects on seed germination in soil and solute systems. American Journal of Botany 57: 413-419.

Lacerda, L. D. \& Hay, J. D. 1992. Habitat of Neoregelia cruenta (Bromeliaceae) in coastal sand dune of Maricá, Brazil. Revista de Biologia Tropical 30: 171-173.

Leishman, M. R.; Westoby, M. 1994. The role of seed size in seedling establishment in dry soil conditions - experimental evidence from semi-arid species. Journal of Ecology 82: 249-258.

Leishman, M. R.; Westoby, M. \& Jurado, E. 1995. Correlates of seed size variation: a comparison among five temperate floras. Journal of Ecology 83: 517-530.

Mantovani, A. 1999a. Leaf morpho-physiology and distribution of epiphytic aroids along a vertical gradient in a Brazilian Rain Forest. Selbyana 20: 241-249.

1999b. A method to improve leaf succulence quantification. Brazilian Archives of Biology and Tecnology 42: 9-14. 
2000. Leaf orientation in hemiepiphytic and holo-epiphytic aroids: significance to the leaf water and temperature balance. Leandra 15: 91-103.

. 2002. Bromélias terrestres na restinga de Barra de Maricá: alocação de recursos na floração, germinação de sementes, estabelecimento e papel facilitador. Tese de Doutorado. Universidade Federal do Rio de Janeiro.

Mantovani, A. \& Rios, R. I. 2001. Bromélias terrestres na restinga de Barra de Maricá, RJ: influência sobre o microclima, o solo, e a estocagem de nutrientes em ambientes de borda de moitas. Leandra 16: 17-37.

2005. Quando aparece a primeira escama? Estudo comparativo sobre o surgimento de escamas de absorção em três espécies de bromélias terrestres de restinga. Rodriguésia 56: 73-84.

Maun, M. A. 1994. Adaptations enhancing survival and establishment of seedlings on coastal dune systems. Vegetation 111: 59-70.

Meyer, S. E; Allen, P. S. \& Beckstead, J. 1997. Seed germination regulation in Bromus tectorum (Poaceae) and its ecological significance. Oikos 78(3): 475-485.

Michel, B. E. \& Kaufmann, M. R. 1972. The osmotic potential of Polyethylene Glycol 6000. Plant Physiology 51: 914-916.

Mohr, H. \& Schopfer, P. 1995. Plant physiology. Springer-Verlag, Berlin, 629p.

Mondragón, D.; Durán, R. ; Ramírez, I. \& Olmsted, I. 1999. Population dynamics of Tillandsia brachycaulus Schtdl. (Bromeliaceae) in Dzibilchaltun National Park, Yucatán. Selbyana 20: 250-255.

Oeser, R. 1991. Easy methods for raising some bromeliads from seed. Journal of Bromeliad Society 41: 25- 27.

Pérez-Fernandez, M. A.; Lamont, B. B.; Marwick, A. L. \& Lamont, W. G. 2000. Germination of seven exotic weeds and seven native species in south-western under steady and fluctuating water supply. Acta Oecologica 21: 323-336.

Pinheiro, F. \& Borghetti, F. 2003. Light and temperature requirements for germination of seeds of Aechmea nudicaulis (L.)
Griesebach and Streptocalyx floribundus (Martius ex Schultes F.) Mez (Bromeliaceae). Acta Botanica Brasilica 17(1): 27-35.

Probert, R. J.; Smith, R. D. \& Birch, P. Germination responses to light and alternating temperatures in European populations of Dactylis Glomerata L. New Phytologist 99: 305-316.

Reilly, R. 1991. Tillandsias: seed gathering and propagation of the species Journal of Bromeliad Society 41: 27- 28.

Reinert, F.; Roberts, A.; Wilson, J. M.; Ribas, L.; Cardinot, G. \& Griffiths, H. 1997. Gradation in nutrient composition and photosynthetic pathways across the Restinga vegetation of Brazil. Botanica Acta 110: 135-142.

Rockwood, L. L. 1985. Seed weight as a function of life form, elevation and life zone in Neotropical Forests. Biotropica 17: 32-39.

Rutledge, A. \& Kendall, H. 1989. Neoregelias from seed to seed. Journal of Bromeliad Society 39: 157-161.

Santana, D. G. \& Ranal, M. A. A. 2004. Análise da germinação: um enfoque estatístico. Ed. UnB, Brasília, 248p.

Silva, J. G. \& Somner, G. V. 1984. A vegetação de restinga na Barra de Marica, RJ. In: Lacerda, L. D.; Araujo, D. S. D.; Cerqueira, R. \& Turcq, B. (eds.). Restingas; origens, estruturas e processos. Restingas: origens, estruturas e processos. CEUFF, Rio de Janeiro. Pp 217-225.

Simon, E. W. \& Mills, L. K. 1982. Imbibition, leakage and membranes. Recent Advances in Phytochemistry 17: 9-27.

Wendt, T. 1997. A review of the subgenus Pothuava (Baker) Baker and Aechmea Ruiz \& Pav. (Bromeliaceae) in Brazil. Botanical Journal of Linnean Society 125: 245-271.

Zaluar, H. L. T. \& Scarano, F. R. 2000. Facilitação em restingas de moitas: um século de buscas por espécies focais. In: Esteves, F. A. \& Lacerda, L. D. Ecologia de restingas e lagoas costeiras. NUPEM/UFRJ, Macaé. Pp. 3-23.

Zar, J. H. 1996. Biostatistical Analysis. $3^{\text {rd }}$ ed. Prentice Hall, New Jersey, 663p.

Zotz, G. 1997. Substrate use of 3 epiphytic bromeliads. Ecography 20: 264-270. 